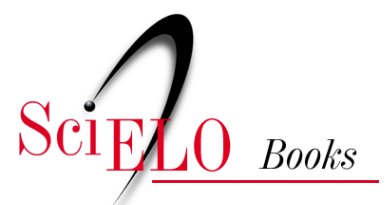

\title{
2. A reforma psiquiátrica e a transição paradigmática
}

\author{
Silvio Yasui
}

\section{SciELO Books / SciELO Livros / SciELO Libros}

YASUI, S. A reforma psiquiátrica e a transição paradigmática. In: Rupturas e encontros: desafios da reforma psiquiátrica brasileira [online]. Rio de Janeiro: Editora FIOCRUZ, 2010, pp. 75-112. Loucura \& Civilização collection. ISBN 978-85-7541-362-3. https://doi.org/10.7476/9788575413623.0004.

International license.

Todo o conteúdo deste trabalho, exceto quando houver ressalva, é publicado sob a licença Creative Commons Atribição $\underline{4.0}$. 


\section{A REFORMA PSIQUIÁTRICA E A TRANSIÇÃO PARADIGMÁTICA}

O real não está na saida nem na chegada, ele se dispóe pra gente é no meio da travessia.

Guimarães Rosa

“- Os raios de sol estão me atravessando."

Seu rosto crispado pela angústia denunciava o sofrimento de Zé. Em uma paulistana manhã fria de inverno, enquanto outros usuários estavam no sol para se aquecer, sentei-me ao seu lado. Essa frase, dita ao vento sem direção, me tomou por inteiro. Alucinação? Vivência psicótica? Todavia, logo meu pensamento se voltou para algo mais próximo. Lá estava ele, com aquela fisionomia marcada por uma profunda dor. A única coisa que pude pensar foi: "- Então vamos sair do sol”. Falei alto o que pensei. Olhou para mim e disse: “- Vamos! Fica comigo?”. Caminhei ao seu lado para dentro do casarão do Caps. Na sombra, a angústia de seu rosto se desfez. Perguntou-me se não queria jogar tênis de mesa. Terminamos aquela fria manhã numa intensa e aquecedora partida.

Neste pequeno fragmento de cena que vivenciei no Caps Luiz Cerqueira, duas diferentes aproximaçôes: na primeira, olhava para aquela dor, buscando defini-la e enquadrá-la em algum critério semiológico que me ajudasse a determinar um provável diagnóstico. Definido o quadro, poderia, então, pensar na melhor conduta, no melhor agir para aquele momento. Colocava em ação um arsenal teórico-conceitual, que busca objetivar aquelas sensações e sentimentos, transformando-os em sintomas de uma doença. 
Em um segundo momento, percebi que havia algo mais a ser ouvido. Havia na dor e na angústia daquelas palavras algo que pedia tradução. Um sofrimento que buscava sentido. Um desafio complexo. Corri o risco e interferi na relação, propondo algo que pudesse ao menos possibilitar um encontro. Inventamos uma saída, ainda que momentânea, para aquela angústia ou para aquele frio.

Doença do corpo ou sofrimento psíquico? Relação positiva entre o sujeito do saber e o seu objeto ou encontro intersubjetivo? Padrōes protocolados de conduta ou intervenção/invenção criadora? Diferentes formas de olhar e de ouvir que implicam diferentes formas de atuar e intervir. Modelos de discursos, de produçôes de saber e de práticas sobre a realidade: um, que representa um modelo hegemônico de pensar e nos fala de uma racionalidade científica médica com suas características (isolar, observar, classificar, determinar); outro, que se espanta com o acaso e o incorpora, buscando compreender esse complexo mosaico do viver e do sofrer.

Modos de pensar, ver, escutar e compreender a realidade que se contrapóem em muitos aspectos. Neste raiar do século XXI, os debates nascidos em meados do século passado sobre um profundo questionamento das bases da racionalidade moderna, fundamento da racionalidade médica, ganham na agenda da saúde um importante espaço. De Bachelard a Morin, de Canguilhem a Foucault, para ficar apenas em alguns autores, muito se tem produzido sobre uma crítica ao paradigma científico moderno e a sua crise que afeta e modifica a produção de saberes em distintos campos.

Credita-se a Thomas Kuhn a ampla divulgação e utilização do conceito de paradigma. Para o autor, a ciência caminha por rupturas ou revoluções. ${ }^{30}$ $\mathrm{O}$ interesse nesse conceito está em contrapor a ideia de que há uma linearidade e continuidade na produção científica que leva ao seu progresso. Kuhn (2000) estabelece um momento que nomeia de "ciência normal", no qual há uma série de suposiçôes, métodos e problemas típicos, que determinam para uma comunidade científica quais são as questôes importantes e qual a melhor maneira de responder a elas, ou seja, há um paradigma. Uma revolução científica acontece, quando surgem "anomalias", isto é, fenômenos ou fatos que não são explicados pelo paradigma vigente e que obrigam a comunidade científica a produzir um novo paradigma, inexistente até então.

${ }^{30}$ Gaston Bachelard foi o primeiro a utilizar o conceito de "ruptura epistemológica", conforme abordarei mais à frente. Destaco aqui que Almeida Filho (2000) aponta para algumas intrigantes coincidências conceituais entre o texto de Bachelard e o de Kuhn. 
Embora sofra muitas críticas por algumas limitações e imprecisōes, especialmente por atribuir apenas à comunidade científica o processo de crise e de produção de um novo paradigma, deixando de lado os fatores e determinantes sociais (Vasconcelos, 2002), é um dos conceitos mais empregados em epistemologia. Vários autores, com usos e sentidos diferentes, o retomam como, por exemplo, no conceito de "transição paradigmática" de Boaventura Souza Santos (1987, 2001), e em Morin (2002), por meio do "paradigma da complexidade".

É em um contexto de crítica ao paradigma científico e de sua racionalidade que o processo da Reforma Psiquiátrica desvenda uma importante ruptura com o modo psiquiátrico de olhar e compreender essa estranha e complexa experiência humana que podemos genericamente nomear de loucura. Para Amarante (2003), há uma dimensão epistemológica na Reforma Psiquiátrica que se caracteriza pelo conjunto de questôes situadas na produção dos saberes e que demandam a desconstrução dos conceitos fundantes da psiquiatria, tais como doença mental, alienação, isolamento, terapêutica, cura, saúde mental, normalidade, anormalidade. Além disso, suscitam a reconstrução/invenção de um novo marco teórico e de novos operadores conceituais.

Trata-se não apenas de um novo olhar para o mesmo objeto, mas de uma ruptura epistemológica que descortina um campo complexo de dimensões do real e nos instiga a produzir conhecimento sobre as relações possíveis de serem feitas, construídas, tecidas. Produção de novos conceitos para novos problemas e objetos.

Produção em consonância com o debate sobre a ciência moderna que aponta, também, a uma "nova aliança", entre as ciências humanas e naturais, como ressaltam Prigogine e Stengers (1997), e para a emergência de um novo paradigma nas ciências: um conhecimento prudente para uma vida decente, como proposto por Boaventura Souza Santos (1987, 2001, 2004); um paradigma da complexidade, como nomeia Morin (2002); ou um novo paradigma ético-estético-político, como postula Guattari (1992).

Neste capítulo, pretendo traçar algumas características do paradigma da racionalidade científica moderna e de seus efeitos na racionalidade médica e psiquiátrica. A seguir, situo o processo da Reforma Psiquiátrica no interior da crise dessa racionalidade, indicando para um período de transição entre paradigmas, destacando as características de um paradigma emergente. Longe de esgotar tão complexo tema, tenho como objetivo fornecer 
alguns elementos que possam contribuir para uma reflexão sobre as características, implicações e consequências dessa dimensão epistemológica.

\section{RACIONALIDADE CIENTÍFICA MODERNA}

Para Touraine (2002), a ideia da modernidade, em sua forma mais ambiciosa, é a afirmação de que o homem é o que ele faz, o que estabelece uma estreita correspondência entre a produção, tornada mais eficaz pela ciência, a organização da sociedade, regulada pela lei, e a vida pessoal, animada pelo interesse e pela vontade de se libertar de todas as opressóes.

Essa correspondência entre cultura científica e uma sociedade ordenada e de homens livres repousa sobre o triunfo da Razão. Somente ela estabelece uma relação entre a ação humana e a ordem do mundo, "anima a ciência e suas aplicações, comanda a adaptação da vida social às necessidades individuais e coletivas e substitui a arbitrariedade e a violência do Estado, pelo direito e pelo mercado" (Touraine, 2002: 9), proporcionando à humanidade o progresso rumo à abundância, à liberdade e à felicidade. Esse é o ideário da modernidade, que tem na racionalidade científica um dos seus pilares de sustentação. Um olhar mais atento sobre a condição da humanidade, neste início de milênio, o qual será retomado mais adiante, basta para demonstrar o quanto esse ideário, séculos após, não se cumpriu.

A racionalidade científica da modernidade nasceu no século XVI, não de uma evolução ou de um acúmulo de saberes, mas de uma ruptura de visão e de uma organização de mundo caracterizado como um saber contemplativo, teocêntrico, formal e finalista, no contexto de profundas transformaçōes econômicas, sociais, políticas e culturais, iniciadas com a Renascença, que caracterizaram a transição do mundo feudal para a modernidade.

Tal ruptura não criou apenas uma cisão entre o divino e o humano. A Natureza não será mais vista como um conjunto de forças situado para além da compreensão humana, com a qual o homem deve relacionar-se com reverência, temor, cumplicidade, conjuração, identificação. Essa ruptura criou uma cisão "também entre ordem humana e ordem natural. Separam-se Deus, homem e natureza” (Luz, 2004: 45). Somente a Razão permite operar com os fenômenos naturais, para submetê-los ao poder do homem, à sua dominação. A Natureza foi esvaziada de uma alma, isto é, de um poder que tanto podia auxiliar quanto aterrorizar. A Razão produziu um "desencantamento" 
do mundo, como nos fala Max Weber (2004). Por isso, o progresso do conhecimento é o progresso do domínio e o Iluminismo é a passagem do mito à Razão esclarecida. O homem afirmou-se como senhor da Natureza.

Madel Luz cita Fritjof Capra, o qual, em seu livro Ponto de Mutação (2004), enfatiza as metáforas utilizadas no início do século XVII, pelo filósofo Francis Bacon, sobre a relação entre o homem da ciência e a Natureza, que deveria ser "acossada em seus descaminhos", "obrigada a servir", "escravizada", com o objetivo de "extrair da natureza, mesmo sob tortura, todos os seus segredos".

A existência objetiva e independente da Natureza é condição epistemológica e ontológica para que o homem possa exercer sobre ela o seu domínio, conhecendo, moldando, transformando, impondo a sua marca: a ordem da Razão. Ao perder o caráter de divino e ao ser dissociada do humano, a Natureza ganhou uma objetividade material, passou de força a coisa: tornou-se objeto. E a Razão, sujeito do conhecimento. Luz (2004: 52) complementa: "A razão torna-se, assim, condição fundamental de apropriação do objeto pelo sujeito, de sua sujeição. Mas trata-se de uma razão instrumentada pela observação repetida, repertoriada, tecnificada. Uma razão demiúrgica, construtora”.

Os filósofos da Escola de Frankfurt, como Adorno, Benjamin, Horkheimer, Marcuse e Habermas, ${ }^{31}$ nomearam essa relação entre o sujeito do conhecimento e o seu objeto, norteada pela necessidade de dominar e controlar, como Razão Instrumental ou Razão Iluminista. Domínio e controle se exercem sobre a Natureza, por meio de uma formalização metódica, matematizante, retirando sua força, sua vida: reificando-a. E se exercem também sobre a sociedade, sobre os homens. Os fenômenos da ordem humana submetem-se a essa Razão Instrumental, tornando-se objetos manipuláveis, negando a sua dimensão histórica e a sua dimensão humana. A reificação do sujeito é, nessa perspectiva, a única possibilidade de conhecêlo. Somos objetos, coisas, subjugados a uma administração regida pelos parâmetros da racionalidade instrumental. Como consequência, nós nos alienamos de nossas açōes como sujeitos construtores da história. Na realidade sócio-histórico-cultural, não existem as contradições entre os diferentes interesses humanos. Existe apenas um grande projeto racional que, ao

\footnotetext{
${ }^{31}$ Algumas obras em que esse conceito pode ser encontrado: Adorno e Horkheimer (1985); Marcuse (1969) e Habermas, (1980). Para uma síntese da Teoria Crítica da Escola de Frankfurt, ver Freitag (1994).
} 
final e ao cabo, nos levará à felicidade. Trata-se aqui de um projeto ideológico. As ideias de progresso técnico e neutralidade científica sucumbem à lógica que determina a adequação dos meios aos fins, das necessidades do mercado da sociedade capitalista. Não mais reflexão sobre valores, porém, sim, sobre eficiência e eficácia.

Para Foucault (1979), a apropriação do objeto pelo sujeito do conhecimento tem seus ritos e critérios. A Verdade não é descoberta, elucidada como numa trama de investigação policial, em que se espreita à espera de um momento certo para desvendá-la, revelá-la. De forma diferente, tem instantes propícios, lugares privilegiados, não só para sair da sombra, como para realmente se produzir. Podemos encontrar toda uma 'tecnologia' desta verdade: levantamento de suas localizações, calendário de suas ocasióes, saber dos rituais. A racionalidade científica, com seu rigor e critério, constitui-se em um modo de produzir verdades.

O laboratório é o lócus privilegiado dessa produção. Retira-se o objeto da complexidade da Natureza isolando, esquadrinhando, criando e controlando circunstâncias e momentos, busca-se reproduzir, observar e deduzir conclusões sobre ele. É entre quatro paredes que a verdade sobre o objeto deverá ser submetida ao ritual de sua prova final, de verdade, com critério, lógica e rigor.

O rigor científico é garantido pelo rigor dos cálculos e das mediçôes. Ao extrair da matemática sua lógica de investigação e seu instrumento privilegiado de análise, têm-se duas principais consequências que caracterizam o método da racionalidade científica moderna: a primeira é que conhecer significa quantificar. As qualidades do objeto serão menos importantes do que as suas características que possam ser quantificadas e mensuradas. A segunda é que conhecer significa simplificar. Ou seja, o método científico assenta-se na redução da complexidade. Para conhecer é necessário dividir, classificar e, depois, estabelecer as relações entre as partes.

O conhecimento científico é causal e aspira à formulação de leis, à luz de regularidades observadas, com vista a prever o comportamento futuro dos fenômenos. Isso pressupóe a ideia de ordem e de estabilidade do mundo, a ideia de que o passado se repete no futuro. $\mathrm{O}$ mundo é uma máquina, cujas operaçôes podemos determinar, decompondo suas partes e estabelecendo relaçôes. $\mathrm{O}$ modelo newtoniano do mundo-máquina é a melhor imagem para sintetizar a grande hipótese universal da época moderna: o mecanicismo. 
Santos (1987: 17) observa: "O determinismo mecanicista é o horizonte certo de uma forma de conhecimento que se pretende utilitário e funcional, reconhecido menos pela sua capacidade de compreender profundamente o real do que pela capacidade de o dominar e transformar".

As disciplinas naturais forneceram aos homens da ciência, tradutores do domínio da Natureza, os instrumentos mais indicados e eficazes para tornar real essa apropriação. Luz destaca três elementos de síntese epistemológica comuns aos filósofos e cientistas: o modelo explicativo (mecanicista), o método (experimentalista e dedutivista) e a linguagem (matematizante). Sublinha que

esta síntese converteu-se em um dos traços básicos da racionalidade moderna, sendo um exemplo para a totalidade das disciplinas, ampliando-se posteriormente do campo racional da produção de verdades para outros domínios da ação e da criação humanas: para as técnicas (com a tecnologia), para o trabalho (com a ergonomia, a administração do trabalho), para as artes (com a institucionalização das Academias), para a moral e os costumes (com a ética e a política racionalista), e mesmo para certas instituições do período clássico (asilos psiquiátricos, prisão, escolas, hospitais) que adotaram como ideal ortopédicosocial o modelo racionalista mecanicista. (Luz, 2004: 80-81)

Modelo, método e linguagem que caracterizam um regime de produção de verdade, no qual as suas regras de produção são mais importantes do que os objetos que investigam. A partir do século XVIII, o modelo de racionalidade científica se impôs como modelo global e totalitário. Apenas uma certeza, um dogma: o da ciência como caminho único para obtenção da verdade, para o processo de sua produção. Estrada única que nega o caráter racional de todas as formas de conhecimento que não se pautam pelos seus princípios epistemológicos e por suas regras metodológicas.

\section{RACIONALIDADE CIENTÍFICA MÉDICA}

A medicina científica moderna nasceu a partir de uma ruptura com as velhas concepções sobre o organismo humano. A arte de curar indivíduos doentes se transformou, gradativamente, em uma disciplina sobre as doenças. Acrescenta Luz (2004: 122), 
O sistema classificatório das morbidades, conduzido pelos médicos do Renascimento e da época clássica, busca seu modelo, em termos de observação (sistemática, ordenatória, empírica) e de modo de pensar as doenças (classificatório, agindo também por analogias e metáforas de similaridades) nas disciplinas da botânica e - depois - da história natural.

Esse modelo impõe compreender a doença como um fenômeno da Natureza: com suas espécies, características observáveis, curso e desenvolvimento. A doença é Natureza, mas uma natureza que exerce uma ação particular sobre um corpo individual. Os clínicos procuraram, no leito dos doentes ou no microscópio do século XVII, as evidências que apontavam para esta ou aquela doença.

Ao longo da época clássica, a prática clínica foi se transformando, com a reorganização dos hospitais como espaço clínico, em uma ciência das entidades patológicas.

Antes do século XVIII, a função essencial do hospital era prestar assistência aos pobres e, também, separá-los e excluí-los. O pobre doente era perigoso e o hospital deveria estar presente tanto para recolhê-lo, quanto para proteger os outros do perigo que ele encarnava. É um lugar de internamento, onde se justapunham e se misturavam não apenas doentes, mas igualmente loucos, meliantes, devassos, prostitutas etc. - uma espécie de instrumento misto de exclusão, assistência e transformação espiritual, em que a função médica não aparece. Como se fez essa reorganização do hospital? Para Foucault (1979), não foi com base em uma técnica médica que o hospital foi reordenado, porém, essencialmente, a partir de uma tecnologia que pode ser chamada política: a disciplina. Segundo ele:

A disciplina éo conjunto de técnicas pelas quais os sistemas de poder vão ter por alvo e resultado os indivíduos em sua singularidade. É o poder de individualização que tem o exame como instrumento fundamental. O exame é a vigilância permanente, classificatória, que permite distribuir os indivíduos, julgá-los, medilos, localizá-los e, por conseguinte, utilizá-los ao máximo. Através do exame, a individualidade torna-se um elemento pertinente para o exercício do poder. (Foucault, 1979: 107)

A introdução dos mecanismos disciplinares no espaço confuso do hospital permitiu sua medicalização. Essa disciplina tornou-se assunto e poder confiado ao médico, visto que também houve uma transformação no saber 
médico. A formação de uma medicina hospitalar deveu-se, por um lado, à disciplinarização do espaço hospitalar e, por outro, à transformação, no século XVIII, do saber e das práticas médicas.

Em O Nascimento da Clínica, Foucault (1987) realiza uma investigação arqueológica sobre a produção do conhecimento da medicina e sobre a transformação operada na estrutura de sua racionalidade e no domínio de sua experiência. Ele se contrapõe à explicação das histórias factuais da medicina, que atribuem a sua transformação em ciência empírica por uma evolução conceitual e epistemológica advinda de um refinamento que determinou mais precisamente os conceitos e noções, e da utilização de instrumentos que permitiram ver melhor o que não se enxergava. A medicina moderna nasceu de rupturas: "o conflito não é entre um saber jovem e velhas crenças, mas entre duas figuras de saber" (Foucault, 1987: 144).

Roberto Machado, analisando esse texto de Foucault, destaca que

a ruptura que inaugura a medicina moderna éo recorte de um novo domínio, é a demarcação de um novo espaço: a passagem de um espaço da representação, ideal, taxonômico, superficial, para um espaço objetivo, real, profundo. Mais explicitamente, a passagem de um espaço de configuração da doença, considerada como espécie nosográfica, para um espaço de localização da doença, o espaço corpóreo individual. (Machado, 1988: 98)

É o "olhar de superfície" de Bichat ${ }^{32}$ que transpôs o olhar médico do espaço ideal das categorias nosográficas da medicina classificatória para a espessura e o volume do espaço corporal da medicina anatomoclínica. Foucault (1987: 155) enfatiza:

Na experiência anátomo-clínica, o olho do médico deve ver o mal se expor e dispor diante dele à medida que penetra no corpo, avança por entre seus volumes, contorna ou levanta as massas e desce em sua profundidade. A doença não é mais um feixe de características disseminadas pela superfície do corpo e ligadas entre si por concomitâncias e sucessōes estatísticas observáveis; é um conjunto de formas e deformaçōes, figuras, acidentes, elementos deslocados, destruídos ou modificados que se encadeiam uns nos outros, segundo uma geografia que se pode seguir passo a passo. Não é mais uma espécie patológica inserindo-se no corpo, onde é possível; é o próprio corpo tornando-se doente.

\footnotetext{
${ }^{32}$ François Xavier Bichat lançou as bases da medicina clínica do século XIX. Aprofundando o conceito de Magnani, Bichat afirmou que a doença não deveria ser vista como lesões de um órgão, mas sim como lesōes de tecidos específicos.
} 
O hospital se constituiu como o lócus para a produção de uma verdade objetiva sobre o corpo doente. O grande laboratório que possibilita um olhar que esquadrinha, observa, anota, cataloga, classifica e intervém. Por um lado, o corpo humano, sede das doenças, será aberto, dissecado, objeto do olhar que investigará os órgãos, os tecidos e os sistemas. Por outro, a patologia clínica produzirá uma gramática dos signos do corpo, um discurso sobre a doença. Essa incessante busca das 'causas' das relações entre o corpo e a doença, por meio da observação, descrição e classificação, constitui o objeto fundamental de conhecimento da medicina moderna. Nesse sentido, argumenta Luz (2004: 128): "O mais importante aqui, a questão epistemológica fundamental, é que a medicina, tornando-se uma ciência das doenças, vivendo da morte, transforma a questão da vida - e do homem vivo, embora doente - numa questão metafísica, portanto supérflua para o conhecimento".

Eis a grande contribuição da medicina para a racionalidade moderna: a disciplina das doenças. A doença e o corpo se constituem em positividades, em objetos do discurso científico moderno, através de categorias como entidade mórbida, corpo doente, organismo, fato patológico, lesão, sintoma etc. Por outro lado, excluíram-se, como questōes positivamente tematizáveis, a vida, a saúde, a cura. "A saúde passará a ser vista não como afirmação da vida, mas ausência de uma patologia. A "cura" será substituída pela cessação de sintomas, sobretudo dos sintomas principais, ou "chaves" de uma doença (Luz, 2004: 130).

É assim, da eliminação da doença no corpo dos indivíduos, que nasce a saúde na medicina moderna.

\section{RACIONALIDADE PSIQUIÁTRICA}

Foi no mesmo momento histórico, passagem do século XVII ao XVIII, que o hospital se organizou como instrumento e lócus médico, que a loucura ganhou estatuto de doença mental.

Para Foucault (1979), no período da Revolução Francesa, suprimiu-se o internamento, símbolo da opressão do Antigo Regime (Ancien Régime), como marco de um novo mundo. Porém, os loucos restituídos à liberdade podiam ser perigosos à sua família e ao seu grupo. Assim, as casas de 
internamento foram paulatinamente reservadas aos loucos, que se tornaram os herdeiros naturais do internamento e das medidas de exclusão.

O nascente mundo moderno liberal efetuou uma profunda ruptura com o mundo antigo. Na teoria política e na filosofia, autores como Hobbes, Locke e Rousseau referem-se a um novo homem emergindo em uma nova configuração política, econômica e social. Temas como direitos naturais, livre iniciativa, liberdade individual configuravam o projeto iluminista que buscava, por meio do conhecimento, libertar o homem dos grilhôes que lhe eram impostos pela ignorância e pela superstição. Os homens eram livres e dotados de uma racionalidade que lhes permitia conhecer o real e agir livremente.

A liberdade e a racionalidade constituíam o que é naturalmente próprio do homem. Todavia, e o louco? Segundo Foucault (1979), o louco é aquele que, por sua irresponsabilidade inocente, vem abolir a liberdade, comprometendo a razão. Assim, seu confinamento constituía-se em uma medida, por um lado, de caráter jurídico, retirando dele uma liberdade que por sua própria conduta ele já aboliu. Por outro, internar era organizar a liberdade. A loucura deveria ser conduzida à verdade, à razão, por meio do encontro com o médico, personagem a quem cabia levar o louco de volta à liberdade. Dessa forma, o internamento ganhou uma nova significação: tornou-se medida de caráter médico. A casa de internamento foi transformando seu espaço interno, além de segregação/isolamento, também, em tratamento. A loucura tornou-se objeto médico: ganhou valor de doença.

Os nomes de Pinel e Tuke estão associados à humanização dos métodos do tratamento. Contudo, não romperam com as antigas práticas de internamento: pelo contrário, eles as estreitaram em torno do louco. Tuke, na Inglaterra, montou um asilo que é a reconstituição em torno do alienado de uma 'quase família', onde ele deveria sentir-se em casa. Era submetido, por isso mesmo, a um controle social e moral ininterrupto: a cura significava inculcar-lhe sentimentos de dependência e humildade. Os métodos eram ameaças, castigos, privaçōes alimentares, humilhaçōes, em resumo, tudo o que poderia, ao mesmo tempo, infantilizar e culpabilizar o louco. Pinel, depois de haver "libertado os acorrentados", reconstituiu em torno deles um encadeamento moral, que transformou o asilo em uma espécie de instância perpétua de julgamento: o louco era vigiado nos seus gestos, rebaixado nas suas pretensões; contradito no seu delírio, ridicularizado nos seus erros: a sanção tinha de seguir imediatamente qualquer desvio em relação a uma conduta normal. 
A doença mental tornou-se uma forma de erro ou de ilusão que se confrontava com certa normalidade de condutas. Uma desordem que se manifestava pelas maneiras de agir e sentir, pela vontade e liberdade do homem. O médico estava encarregado de efetuar mais um controle moral do que uma intervenção terapêutica. Ele era, no asilo, o agente das sínteses morais.

Foucault (1979: 122) apresenta uma função que o hospital psiquiátrico teve no século XIX:

lugar de diagnóstico e de classificação, retângulo botânico onde as espécies de doenças são divididas em compartimentos cuja disposição lembra uma vasta horta. Mas também espaço fechado para um confronto, lugar de uma disputa, campo institucional onde se trata de vitória e de submissão. O grande médico do asilo (...) é ao mesmo tempo aquele que pode dizer a verdade da doença pelo saber que dela tem, e aquele que pode produzir a doença em sua verdade e submetê-la, na realidade, pelo poder que sua vontade exerce sobre o próprio doente.

Por outro lado, em 1822, surgiu um modelo médico para a concepção da doença mental que abalou as teses do tratamento moral. Bayle, ${ }^{33}$ na mesma linha de trabalho iniciada por Bichat, caracterizou as lesões cerebrais na paralisia cerebral, denominando-as de "aracnite" e "meningite crônica”, e relacionou as perturbaçóes morais dos pacientes com essas lesões. Birman (1978: 52) afirma:

Construiu assim a primeira enfermidade mental de acordo com a racionalidade médica. Esta era fundada na Anatomia patológica, que dava a razão última de ser para as manifestaçōes clínicas: as enfermidades seriam um conjunto de sintomas e sinais, sendo estes os fenômenos superficiais que expressavam uma lesão corporal. A doença estaria localizada no plano profundo do corpo, nos órgãos e tecidos alterados, mas manifestando-se por signos aparentes.

Os estudos de Bayle ofereceram o argumento anatomopatológico para um diagnóstico objetivo e para a conduta terapêutica, possibilitando também um modelo de investigação. Há que enumerar e descrever exaustivamente as manifestaçôes exteriores, os sintomas, para caracterizar as diferentes patologias que, em última análise, são os desregramentos das funções cerebrais. Era a psiquiatria em busca de um corpo para sua doença.

${ }^{33}$ Seu nome completo era Antoine Laurent Jesse Bayle e sua tese de 1822 intitulou-se "Recherches sur l'Arachinite Chronique". 
A subjetividade se exterioriza, se torna uma verdade positiva, ou seja, uma realidade passível de observação científica. Este é o fundamento para toda uma 'ciência' baseada nas evidências dos sintomas e sinais: a psicopatologia. E, como objeto de conhecimento, a loucura só poderá ser abordada pelo médico, delegado da Razão. A experiência humana da loucura desapareceu. Em seu lugar, surge um discurso da racionalidade que define quem está privado dela. As correntes que aprisionam a loucura já não são feitas de ferro, mas, sobretudo, de palavras.

Chauí (1980: 2) nomeia isso como "discurso competente", que pode ser assim caracterizado: "não é qualquer um que pode dizer qualquer coisa a qualquer outro em qualquer ocasiāo e em qualquer lugar”. Há assuntos, momentos e pessoas adequados para o saber ser enunciado. Foucault (2004), partindo de uma questão semelhante sobre o discurso, aponta para três tipos de interdição que se cruzam, se reforçam e se compensam, como consequência desse tipo de enunciado: há um tabu do objeto, um ritual da circunstância e um direito privilegiado do sujeito que fala. Só algumas pessoas, em circunstâncias especiais, podem falar sobre determinados objetos.

Falar cientificamente sobre a subjetividade humana expressa nas emoções, afetos, percepções, pensamentos é falar de um campo marcado por uma racionalidade que exclui qualquer outra forma de saber que não se guie pelos cânones da ciência: objetividade expressa na utilização do método científico que produza evidências experimentais que demonstrem a determinação material da patologia mental.

O discurso psiquiátrico como discurso do especialista sobre a loucura não é apenas uma prática médica, é uma Razão Instrumental. Para Adorno e Horkheimer (1985), a Razão, sujeito abstrato da história individual e coletiva do homem, afirmado em Kant e Hegel, converteu-se em uma razão alienada. O ideal iluminista da razão como instrumento de libertação, como realização da autonomia e da autodeterminação do homem, fracassou. Desviou-se de seu objetivo emancipatório e tornou-se uma Razão Instrumental, que submete a Natureza ao seu controle totalitário e exerce uma dominação incondicional dos homens. Conforme Marcuse (1969), a ciência e a técnica são usadas para dominar a natureza e, com isso, acelerar a produção por meio da dinamização das forças produtivas. A mesma ciência é utilizada para dominar os homens, pois eles se subordinam cada vez mais ao processo produtivo acelerado pela ciência e tecnologia. Nesse sentido, tornaram-se, 
elas mesmas, forças produtivas a serviço do capital, contribuindo para a manutenção das relações sociais. Afirma o autor que "talvez o próprio conceito de ciência e tecnologia seja ideologia" (Marcuse, 1969: 127). Habermas (1980) radicaliza essa tese, afirmando que ciência e técnica efetivamente se transformaram em ideologia, quer dizer, ambas passaram a ser a base de legitimação indispensável do moderno Estado capitalista.

Nessa perspectiva, afirmamos que a psiquiatria é o discurso que instrumentaliza e legitima uma intervenção política, uma prática disciplinadora, mediadora da sutil violência repressiva que caracteriza as sociedades contemporâneas. Após a Segunda Guerra Mundial, a psiquiatria vai deixar as grandes anomalias e voltar-se para a 'saúde mental', para a prevenção dos desvios. Não se trata mais de corrigir, mas de educar para produzir um indivíduo saudável e de prever a doença, antecipando-se onde houver comportamentos de risco, desviantes de norma. As reformas propostas pela psiquiatria comunitária norte-americana e pela psiquiatria de setor francesa concretizam esse ideal, como pode ser visto em Birman e Costa (1994), Amarante (1998) e Fleming (1976).

Com um afã de domínio e controle, a psiquiatria sempre buscou afirmar-se como um conhecimento científico, aplicando o modelo da racionalidade moderna ao funcionamento do psiquismo. Porém, sempre encontrou grandes dificuldades em se constituir como uma especialidade com um saber advindo da racionalidade médica. Birman (2001: 180-181) escreve: "O discurso da anatomoclínica, base epistemológica da dita medicina científica, não encontrava legitimidade no campo da psiquiatria. A psiquiatria buscava as causas físicas dos distúrbios mentais e apenas encontrava, desde Pinel e Esquirol, as causas morais".

As descobertas da psicofarmacologia, nos anos 50 do século XX, e, sobretudo, nos anos 80 e 90, com o desenvolvimento das neurociências, renovaram as aspirações da psiquiatria em conquistar seu status de ciência. Nessa pretensão, segue o modelo global e totalitário da racionalidade científica, negando e/ou invalidando toda forma de conhecimento sobre o psiquismo que não se guia pelos princípios epistemológicos e por suas regras metodológicas. Assim, as classificações adotadas oficialmente, como o Manual de Diagnóstico e Estatística das Perturbações Mentais, 4a edição (DSM-IV), da Associação Psiquiátrica Americana, e o Código Internacional de Doenças, $10^{a}$ edição (CID-10), da OMS, reproduzem um esforço para 
unificar de forma totalizadora os diagnósticos das doenças mentais. Pretendem que discurso, diagnóstico, raciocínio, método e terapêutica sejam claramente explicitados, baseados em evidência experimental e sustentados pela determinação consensual dos termos a serem usados, os quais representam, para seus formuladores, a tentativa de recuperar a identidade médica da psicopatologia e centrar-se em um sentido claro de ciência. Trata-se de uma classificação consensual que, com o apoio logístico e financeiro dos grandes laboratórios farmacêuticos, deve ser adotada em pacote, método e linguagem, por todos aqueles que, no mundo todo, pretendam praticar a 'boa psiquiatria'. Consensual e excludente, pois não há outra possibilidade de se pensar critérios diagnósticos.

A potencial descoberta e domínio dos processos cerebrais, responsáveis pelos diferentes estados da psique, reduzem o funcionamento psíquico a esses processos e são totalmente explicáveis em uma linguagem neurobioquímica. Assim, por exemplo, a depressão, nomeada por esse modelo de racionalidade como transtorno depressivo, é entendida como uma alteração do estado de humor produzida por uma disfunção na captação da serotonina no nível sináptico, cuja terapêutica adequada é a ingestão de uma classe específica de medicamento. Embora possa haver fatores externos intervenientes, serão sempre secundários e a 'boa conduta médica' indica uma primazia do tratamento psicofarmacológico. Segue-se, aqui, um dos princípios fundamentais da racionalidade científica moderna: simplificar para conhecer. A vida humana é por demais complexa, repleta de nuances, contradições e paradoxos. A tristeza que ela nos causa não pode ser compreendida se todos esses aspectos forem levados em consideração. Portanto, para essa racionalidade, o homem é uma máquina que deve possuir um funcionamento padrão ótimo, e tudo aquilo que se desviar desse padrão/normalidade deve sofrer uma intervenção para readequá-lo, readaptá-lo, corrigi-lo. A depressão é recortada da 'sujeira' da vida cotidiana, isolada e estudada naquilo que de fato conta para esse tipo de ciência: seus processos bioquímicos.

Como ser infeliz em uma sociedade industrial moderna que tudo possibilita? Há um ideal de felicidade contemporânea que pode e deve ser adquirido em pílulas. O sujeito não pode querer 'ficar de fora'. De acordo com Birman (2001: 191): "Na cultura da exaltação desmesurada do eu, não existe mais lugar para os deprimidos e os panicados. Estes são execrados, lançados no limbo da cena social, já que representam a impossibilidade de serem cidadãos da sociedade do espetáculo”. 
Esse autor ressalta que as culturas do narcisismo e do espetáculo, ${ }^{34}$ marcantes em nosso tempo, construíram um modelo de subjetividade em que se silenciam as possibilidades de reinvenção do sujeito e do mundo, impondo ideais e padrões de comportamento totalitários e totalizantes. A psiquiatria, a psicologia, as ciências humanas, de maneira geral, como saber e conhecimento científico e racional sobre o humano, instrumentalizam e legitimam esses ideais e padrões, inseridos em uma lógica de mercado, em que não importa ser, mas consumir. Acena-se com promessas de rápida e imediata satisfação. Mesmo a 'peste' da psicanálise, a que um dia Freud acreditou estar levando a sociedade norte-americana, rendeu-se, ao menos em parte de sua comunidade, a essa lógica, neutralizando o seu potencial crítico e se transformando em uma prática homogeneizadora de subjetividades. Em outro texto, Birman (2005: 221) critica uma parcela da comunidade psicanalítica que, na atualidade, busca construir uma versão tecnológica da psicanálise, por meio da "bricolagem entre o discurso psicanalítico, as neurociências e o cognitivismo", almejando e prometendo o apaziguamento, a cura para os conflitos da existência.

Contudo, a busca solitária e desesperada permanece. A incômoda sensação de desamparo, de desassossego, insiste. $\mathrm{O}$ mal-estar resiste.

Não pretendo aqui menosprezar ou negar que a sociedade contemporânea deve muito aos avanços da ciência moderna, mas afirmar que esta mesma ciência atravessa hoje uma profunda crise e fracassou em suas promessas de progresso e de felicidade, transformando-se em ameaças de destruição. Santos (2001: 56) diz que

a promessa da dominação da natureza, e do seu uso para o benefício comum da humanidade, conduziu a uma exploração excessiva e despreocupada dos recursos naturais, à catástrofe ecológica, à ameaça nuclear, à destruição da camada de ozônio, e à emergência da biotecnologia, da engenharia genética e da conseqüente conversão do corpo humano em mercadoria última. A promessa de uma paz perpétua, baseada no comércio, na racionalização científica dos processos de decisão e das instituiçóes, levou ao desenvolvimento tecnológico da guerra e ao aumento sem precedentes de seu poder destrutivo. A promessa de uma sociedade mais justa e livre, assente na criação da riqueza tornada possível pela conversão da ciência em força produtiva, conduziu a espoliação do chamado Terceiro Mundo e a um abismo cada vez maior entre Norte e o Sul. Neste século morreu

${ }^{34}$ Referência aos trabalhos de Lasch (1983) e Debord (1997), que, para Birman, são instrumentos teóricos agudos para realizar uma leitura das novas formas de subjetivação na atualidade. 
mais gente de fome do que em qualquer dos séculos anteriores, e mesmo nos países mais desenvolvidos continua a subir a percentagem dos socialmente excluídos, aqueles que vivem abaixo no nível de pobreza.

\section{CRISE DO PARADIGMA CIENTÍFICO DA MODERNIDADE}

Santos (1987) aponta para um interessante paradoxo: a identificação dos limites e das insuficiências estruturais do paradigma científico dominante só foi possível graças ao grande avanço que ele mesmo propiciou. Isso leva a ciência moderna a uma crise que, desde o início do século XX, vem causando abalos profundos nos fundamentos que sustentam o discurso e as verdades produzidas por ela.

Esse autor vai buscar nas ciências naturais e na matemática, que alicerçam o modelo da racionalidade científica moderna, quatro condições teóricas da crise do paradigma dominante: a primeira é dada pela "teoria sobre a relatividade da simultaneidade" de Einstein, a qual estabelece uma distinção entre a simultaneidade de acontecimentos presentes no mesmo lugar e os acontecimentos separados por distâncias astronômicas. Ou seja, dois acontecimentos simultâneos em um sistema de referência não são simultâneos noutro sistema. Como exemplo, podemos citar o "paradoxo dos gêmeos". Um dos gêmeos parte em uma viagem espacial a uma velocidade próxima da luz, enquanto seu irmão permanece na Terra. Ao retornar do espaço, por causa de seu movimento, o gêmeo viajante descobrirá, vendo seu irmão mais envelhecido, que o tempo fluiu mais lentamente na espaçonave. Essa teoria revoluciona as concepções newtonianas de tempo e espaço absolutos.

A segunda condição teórica da crise é apresentada pela física quântica. Os estudos de Heisenberg e Bohr operam um profundo questionamento na noção de neutralidade e na separação entre o sujeito e o objeto do conhecimento, ao demonstrar que, no nível quântico, não é possível observar ou medir um objeto sem interferir nele, sem o alterar, e a tal ponto que a simples medição de um objeto o modifica. Do real só conhecemos aquilo que é nosso, quer dizer, a nossa intervenção sobre ele. Heisenberg postula, em seu "princípio da incerteza", que, quando conhecemos perfeitamente as propriedades geométricas de um átomo, não conseguimos conhecer suas propriedades físicas dinâmicas e vice-versa, sendo impossível determinar o 
estado passado e futuro do fenômeno estudado, isto é, suas causas e efeitos. Em todo fenômeno há incerteza e indeterminação.

Disso decorrem as seguintes importantes consequências: o nosso conhecimento está estruturalmente limitado e só podemos aspirar a resultados aproximados. Com isso, o determinismo mecanicista torna-se relativo porque a soma das partes em que dividimos o real, para melhor medir e observar, não corresponde à sua totalidade. Por fim, a separação entre sujeito/ objeto é muito mais complexa do que se supunha, ou seja, não há separação, pelo contrário, há um continuum.

A terceira condição refere-se ao principal instrumento da racionalidade científica moderna: o rigor da matemática. Santos (2001: 70) recorre ao "teorema da incompletude" de Gödel, o qual demonstra que, "mesmo seguindo à risca as regras da lógica matemática, é possível formular proposições indecidíveis, proposiçôes que se não podem demonstrar nem refutar”. Quer dizer, em qualquer proposição axiomática consistente, baseada em aritmética, existem sentenças sobre as quais não é possível decidir se são verdadeiras ou falsas. Por exemplo, em um jogo criado a partir da aplicação perfeitamente lógica de um conjunto fixo de regras, surgirão lances que não podem ser julgados como válidos ou faltosos, de acordo com as suas próprias regras. Estamos frente a frente com um paradoxo. Isso significa que nenhum sistema lógico se basta a si mesmo, nem é capaz de compreender-se sozinho a si mesmo: sempre será necessário um sistema maior e mais complexo para dar conta de tudo que o sistema menor contém. Portanto, existem sentenças aritméticas, formuláveis em uma determinada axiomática baseada em aritmética, que não podem ser provadas ou refutadas.

Kubrusly (2005) apresenta uma situação que permite ilustrar esse paradoxo. Ele conta uma história sobre um barbeiro, em Sevilha, que mandou pendurar na porta de sua casa uma tabuleta com os seguintes dizeres: "Faço a barba de todos que não fazem a própria barba, e somente deles". A pergunta que se pode fazer é: quem faz a barba do barbeiro? Nota-se, primeiramente, que não há barbudos na cidade, pois todos que não fazem a própria barba, a terão feita pelo barbeiro. Logo, o barbeiro faz a própria barba se, e somente se, não fizer a própria barba. A afirmação: "O barbeiro faz a sua própria barba" é verdadeira se, e somente se, for falsa e vice-versa.

Para Santos, ao relativizar o rigor da matemática, estes estudos questionam a afirmação de Galileu de que "o grande livro da natureza está escrito 
em caracteres matemáticos", sintetizando o pensamento da racionalidade científica moderna que encontra o rigor de suas formulações na matemática. Os trabalhos de Gödel demonstram que "o rigor da matemática carece, ele próprio, de fundamento" (Santos, 2001: 70), o que, como consequência, abala a confiabilidade desta racionalidade que se sustenta na frieza e na lógica, até então, inabalável dos cálculos.

A quarta condição é constituída pelos avanços do conhecimento nos domínios da microfísica, da química e da biologia, nos últimos trinta anos, especialmente, a "teoria das estruturas dissipativas" do físico-químico Ilya Prigogine, o qual rompe com o mundo mecânico e determinista, introduzindo uma dimensão totalmente nova do tempo. Sua tese é a de que os processos químicos (da vida) são irreversíveis e dependentes do tempo e compõem o que denomina de estruturas dissipativas - estruturas caóticas, mas que não necessariamente conduzem à desordem. Esses processos irreversíveis são fontes de "novas ordens", que - associadas ao seu caráter randômico e de troca com o meio - levam a níveis mais elevados de organização: "Ordem e desordem mostram-se aqui não como opostos entre si, e sim indissociáveis” (Prigogine \& Stengers, 1992: 54).

A irreversibilidade nos sistemas abertos, ou seja, a quebra de simetria entre um antes e um depois, a noção de acontecimento como fruto de possibilidades, e não de determinação, introduzem a história nos processos físico-químicos. Santos (2001: 70-71) relata:

Em vez da eternidade, a história; em vez do determinismo, a imprevisibilidade; em vez do mecanicismo, a interpenetração, a espontaneidade e a auto-organização; em vez da reversibilidade, a irreversibilidade e a evolução; em vez da ordem, a desordem; em vez da necessidade, a criatividade e o acidente.

Tempo e espaços como não absolutos, interferência do observador no fenômeno, relativização do rigor matemático e auto-organização criativa dos sistemas. $\mathrm{O}$ antigo/moderno mundo estático e sujeito às leis imutáveis e deterministas vai sendo substituído pela visão de um universo instável e dinâmico, reino da incerteza, do acaso e da criatividade.

A esta análise podemos acrescentar a "ferida narcísica" proporcionada pela psicanálise. Em seu artigo "Uma dificuldade no caminho da psicanálise", de 1917, Freud (1980a) conta como o narcisismo universal dos homens sofreu três severos golpes: o primeiro foi dado por Copérnico, que destruiu a ilusão 
de que o domicílio do homem, a Terra, era o centro do universo, com o sol, a lua e os planetas girando ao seu redor, o que o tornava senhor do mundo; o segundo foi provocado por Charles Darwin, ao provar que o homem possui uma ascendência animal, não sendo um ser diferente dos outros animais ou superior a eles; e o terceiro golpe foi contra o amor próprio do homem. Um golpe psicológico desferido pelo próprio Freud, ao afirmar que o ego não é o senhor da sua própria casa, pois as nossas pulsões sexuais não podem ser inteiramente domadas, os nossos processos mentais são inconscientes e somente atingem o ego e a ele se submetem por meio de percepçôes incompletas e de pouca confiança. A consciência não é a essência da vida psíquica, mas apenas uma de suas qualidades. Com isso, o projeto iluminista que colocava a Razão como senhora absoluta do destino da vida e dos desejos do homem sofreu um forte abalo.

Para Freud, há um mais além (e aquém, acima e abaixo) do princípio da razão. Existe o mistério do inconsciente. No lugar do homem racional poderoso e autônomo frente à natureza, temos um sujeito dividido entre a consciência e o inconsciente; temos a incompletude do humano com sua falta inaugural e estruturante, que o lança na aventura da vida como ser desejante; temos o "desamparo" frente aos dilemas da existência.

Vale aqui salientar que Freud nem sempre foi um crítico da razão iluminista. Birman (2005) aponta para os textos freudianos iniciais, em que é evidente sua crença no poder do discurso científico, para promover o "progresso do espírito humano", e do papel que a psicanálise poderia desempenhar, proporcionando a cura das perturbações do espírito e do desamparo humano. Como prova dessa afirmação, Birman cita o texto de 1908, Moral Sexual "Civilizada" e a Doença Nervosa Moderna, no qual Freud (1980c) vislumbra a possibilidade de uma harmonia entre o registro da pulsão e o da civilização.

É a partir de 1915, especialmente com a segunda teoria das pulsões, enunciando o conceito de pulsão de morte, que a crença freudiana nessa harmonia cai por terra. Birman (2005: 213) ressalta:

Com efeito, pela mediação desse novo conceito de pulsão torna-se impossível a concepção de uma harmonia entre o registro da pulsão e o da civilização. Pelo viés da pulsão de morte, concebida agora como silenciosa e não inscrita originariamente no campo da representação, a harmonia com o registro da civilização não se torna mais possível. Portanto, no que tange à espécie humana, a vida seria 
algo a ser conquistado, um vir-a-ser e um destino possível, mas não um valor instituído de maneira originária.

É em Mal-Estar na Civilização, texto de 1930, que Freud demonstra sua descrença na ideia do progresso do espírito humano mediado pelo logos científico, como pode ser visto no trecho a seguir:

Ficamos inclinados a dizer que a intenção de que o homem seja feliz não se acha incluída no plano da Criação (...) nossas possibilidades de felicidade sempre estão restringidas por nossa própria constituição. Já a infelicidade é muito menos difícil de experimentar. O sofrimento nos ameaça a partir de três direçōes: de nosso próprio corpo, condenado à decadência e à dissolução (...); do mundo externo, que pode voltar-se contra nós com forças de destruição; e, finalmente, de nossos relacionamentos com os outros homens. (Freud, 1980b: 95)

E no mesmo texto, mais à frente, Freud (1980b: 102-103) afirma:

O programa de tornar-se feliz, que o princípio do prazer nos impõe, não pode ser realizado; contudo, não devemos - na verdade, não podemos - abandonar nossos esforços de aproximá-lo da consecução, de uma maneira ou de outra. Caminhos muito diferentes podem ser tomados nessa direção, e podemos conceder prioridades quer ao aspecto positivo do objetivo, obter prazer, quer ao negativo, evitar o desprazer. Nenhum desses caminhos nos leva a tudo o que desejamos. A felicidade, no reduzido sentido em que a reconhecemos como possível, constitui um problema da economia da libido do indivíduo. Não existe uma regra de ouro que se aplique a todos: todo homem tem de descobrir por si mesmo de que modo específico ele pode ser salvo.

Há uma dimensão trágica do existir humano. Nosso desamparo diante do mundo coloca a cada homem o desafio de inventar, criar seu próprio caminho. E, para a psicanálise, isso implica uma ética com consequências políticas. Contudo, uma parte da comunidade psicanalítica, conforme mencionei anteriormente, na crítica formulada por Birman (2005), abandonou essa perspectiva, optando por buscar uma articulação com as neurociências e a psicofarmacologia, com promessas de harmonia e de apaziguamento das angústias existenciais, da dor de viver.

A grande contribuição da psicanálise está justamente em apresentar o humano com uma dimensão não racional, inconsciente, marcado por uma falta inaugural que o produz como sujeito desejante, que se aventura pela 
vida, carecendo do Outro para produzir e reproduzir permanentemente sua subjetividade. E é esse sujeito que também produz ciência.

Somando-se à crise dos fundamentos que sustentam o discurso e as verdades produzidas pela ciência moderna, emerge a dimensão subjetiva, com as trajetórias coletivas e pessoais dos sujeitos. O mito de uma ciência neutra, objetiva, vai-se desfazendo, sobretudo quando se coloca em cena a subjetividade neste mundo frio dos cálculos e das experimentações. Surgem então as vaidades, as disputas, os interesses econômicos e políticos que influenciam e são decisivos na definição das prioridades e dos investimentos.

E, nessa ciência em crise, há uma mudança nas bases epistemológicas do paradigma científico se configurando. Como afirma Santos (2001), estamos em um momento de transição paradigmática.

\section{COMPLEXIDADE E O PARADIGMA EMERGENTE}

É a partir dos dilemas colocados à ciência pela física de Einstein, pela geometria não euclidiana, pelo princípio da incerteza de Heisenberg, que Gaston Bachelard propóe uma nova epistemologia, rejeitando a doutrina das naturezas simples e absolutas, apontando para uma complexidade essencial da filosofia científica. "A ciência cria, com efeito, filosofia" (Bachelard, 2000: 12). Pretende mostrar que a ciência contemporânea obrigou-nos a renunciar à pretensão de um saber universal. Vê o filósofo retomando o projeto de compreender a relação do homem com o seu saber.

Bachelard foi filósofo, historiador das ciências, físico, químico e epistemólogo. Hilton Japiassu (1976a: 21) caracteriza sua obra como de uma dupla vertente: uma científica, a outra poética. Ao longo de sua vida, sentiu-se atraído pelo encanto do imaginário poético e passou "a estudá-lo e a valorizá-lo como uma das formas possíveis, não somente de se apreender, mas de se recriar a realidade". Como espistemólogo, propôs um racionalismo 'aberto', uma razão continuamente reformulada pelo próprio progresso do saber científico. Para ele, a ciência é histórica. Sua noção de progresso científico está ligada à descontinuidade, faz-se por rupturas com o senso comum. Japiassu (1976a: 23) enfatiza alguns aspectos em Bachelard: "A ciência, como o homem, não é criação da necessidade, porém do desejo. Por outro lado, é intervencionista. Por isto deve ser feita em uma comunidade de pesquisas e de críticas para não se tornar totalitária”. 
O conceito que sustenta o projeto de Bachelard é o de obstáculo epistemológico:

Quando se procuram as condiçōes psicológicas do progresso da ciência, logo se chega à convicção de que é em termos de obstáculos que o problema do conhecimento científico deve ser colocado. E não se trata de considerar os obstáculos externos, como a complexidade e a fugacidade dos fenômenos, nem de incriminar a fraqueza dos sentidos e do espírito humano. É no âmago do próprio ato de conhecer que aparecem, por uma espécie de imperativo funcional, lentidōes e conflitos. É aí que aparecem causas de estagnação e até de regressão, causas de inércia às quais chamamos de obstáculos epistemológicos. No fundo, o ato de conhecer dá-se contra um conhecimento anterior, destruindo conhecimentos mal estabelecidos, superando o que, no próprio espírito, é obstáculo à espiritualização (...) Quando o espírito se apresenta à cultura científica, nunca é jovem. Aliás, é bem velho, porque tem a idade de seus preconceitos. Aceder à ciência é rejuvenescer espiritualmente, é aceitar uma brusca mutação que contradiz o passado. (Bachelard, 1967: 14-15)

Um outro pensador crítico da ciência, Edgar Morin, observa, no 'projeto' de Bachelard, um conceito pouco trabalhado por ele, porém essencial: a noção de complexidade. Para Morin, o problema da complexidade se tornou uma exigência social e política para o pensamento contemporâneo. A noção de complexidade pode ser entendida como um tecido interdependente, interativo e inter-retroativo entre o objeto do conhecimento e seu contexto, as partes, o todo e as partes entre si. União entre unidade e a multiplicidade.

Por exemplo, se tentamos pensar no fato de que somos seres ao mesmo tempo físicos, biológicos, sociais, culturais, psíquicos e espirituais, é evidente que a complexidade é aquilo que tenta conceber a articulação, a identidade e a diferença de todos esses aspectos, enquanto o pensamento simplificante separa esses diferentes aspectos, ou unifica-os por uma redução mutilante. Portanto, neste sentido, é evidente que a ambição da complexidade é prestar contas das articulações despedaçadas pelos cortes entre as disciplinas, entre categorias cognitivas e entre tipos de conhecimento. (Morin, 2002: 176)

A aspiração a um conhecimento multidimensional poderia aparentar uma formulação de uma totalização unificante e universalizadora. Morin nos alerta para o fato de que essa multidimensionalidade comporta o princípio da incompletude e da incerteza. Ou seja, a complexidade surge como dificuldade, incerteza e não como clareza, como resposta. É, fundamentalmente, o 
desafio de incorporar a desordem, a contradição, a incerteza, o acaso, enfim, todos esses resíduos descartáveis considerados não científicos, na problemática geral do conhecimento científico. Com efeito,

o pensamento complexo é (...) essencialmente o pensamento que lida com a incerteza e que é capaz de conceber a organização. Trata-se de um pensamento capaz de reunir, contextualizar, globalizar, mas ao mesmo tempo de reconhecer o singular, o individual, o concreto. $O$ pensamento complexo não se reduz nem à ciência, nem à filosofia, mas permite uma comunicação mútua, fazendo o intercâmbio entre uma e outra. (Morin, 2003: 77)

É pensando no desafio proposto pela ciência da complexidade, que Prigogine e Stengers (1997) propóem a tese de que o que é válido para a complexidade químico-física é também válido, ou pelo menos útil, para a complexidade que é objeto de estudo das ciências humanas - a sociologia, a história, a filosofia. O título do livro no qual apresentam essa tese resume essa nova possibilidade de confronto e de síntese entre as ciências exatas e as ciências humanas: uma "nova aliança" - entre homem e natureza e entre ciência e filosofia.

Em outro texto, com o sugestivo nome de O Fim das Certezas, Prigogine (1996) afirma:

Assistimos ao surgimento de uma ciência que não mais se limita a situaçôes simplificadas, idealizadas, mas nos põe diante da complexidade do mundo real, uma ciência que permite que se viva a criatividade humana como a expressão singular de um traço fundamental comum a todos os níveis da natureza.

A Natureza se faz e refaz constantemente. Colocar em cena a criatividade nos remete a pensar na arte, que potencializa ao máximo a capacidade de invenção, de nos oferecer novas perspectivas, ainda não pensadas. Trata-se de uma criação que nasce de um incessante ir e vir entre a ordem, o caos e a complexidade. Guattari (1992) nomeia essa concepção de caosmose, para marcar uma relação de osmose ou de imanência entre o caos e a complexidade. Para se pensar essa potencialidade criadora, propõe também um novo paradigma estético, alertando:

O novo paradigma estético tem implicações ético-políticas porque quem fala em criação, fala em responsabilidade da instância criadora em relação à coisa criada, em inflexão de estado de coisas, em bifurcação para além de esquemas 
preestabelecidos (...). Mas essa escolha ética não mais emana de uma enunciação transcendente (...). A própria gênese da enunciação encontra-se tomada pelo movimento de criação processual. Isto é bem nítido no caso da enunciação científica, que tem sempre uma cabeça múltipla: a cabeça individual, é claro, mas também cabeça coletiva, cabeça institucional, cabeça maquínica com os dispositivos experimentais, a informática com os bancos de dados e a inteligência artificial... (Guattari, 1992: 137)

A Reforma Psiquiátrica se caracteriza por uma ruptura em relação à racionalidade psiquiátrica, ao recusar-se a aceitar o sofrimento humano apenas como o objeto simples da doença mental, mas por considerá-lo em sua complexidade. É do diálogo entre as diferentes e diversas disciplinas que cuidam desse sofrimento que se cria uma nova maneira de olhar, de escutar, de cuidar. Para Rotelli, Leonardi e Mauri (2001), se o objeto não é mais simples (a doença), a tarefa é criar, inventar instituições, as quais devem se renovar a cada novo encontro com os usuários, pois cada história de vida nos apresenta a complexidade da vida. Novamente recorremos a Riobaldo, personagem do livro Grande Sertão: veredas, de Guimarães Rosa (1985: 21), que sintetiza o que podemos pensar ser a meta mais radical de uma instituição inventada: "o mais importante e bonito, do mundo, é isto: que as pessoas não estão sempre iguais, ainda não foram terminadas - mas que elas vão sempre mudando. Afinam ou desafinam”.

As palavras 'incerteza', 'desafios', 'riscos', 'curiosidade' estão sempre presentes ao se falar em complexidade. Essas mesmas palavras definem bem o sentimento daquele que busca compreender a aventura chamada loucura. Colocam-nos em movimento, na busca de construir pontes que nos levem à possibilidade de um diálogo com essa 'complexa vivência humana'.

Boaventura Souza Santos é outro autor que aponta para um período de transição de paradigma. Por ser uma transição, só podemos vislumbrar sinais de um novo conhecimento constituído pelo que ele chama de "paradigma de um conhecimento prudente para uma vida decente". Afirma a atual revolução científica como estruturalmente diferente daquela do século XVI, que marcou o nascimento da ciência moderna:

Sendo uma revolução científica que ocorre numa sociedade ela própria revolucionada pela ciência, o paradigma a emergir dela não pode ser apenas um paradigma científico (o paradigma de um conhecimento prudente), tem e ser também um paradigma social (o paradigma de uma vida decente). (Santos, 1987: 37) 
Para ele, o conhecimento produzido por esse novo paradigma deve apresentar as seguintes características:

- Todo conhecimento científico-natural é científico-social.

As contribuições da física e da biologia, já destacadas anteriormente, como os conceitos de auto-organização ou a teoria das estruturas dissipativas de Prigogine, introduzem na matéria os conceitos antes exclusivos da ordem do humano, como historicidade e autonomia, superando a distinção decretada no século XVI, entre o Homem e a Natureza. Santos (1987: 38) argumenta: "É como se o homem e a mulher se tivessem lançado na aventura de conhecer os objetos mais distantes e diferentes de si próprios, para, uma vez aí chegados, se descobrirem refletidos como num espelho".

Como exemplo, apresento as cenas finais do filme 2001: uma odisseia no espaço, de Stanley Kubrick, que podem ilustrar esse encontro. Depois de haver derrotado o supercomputador e após uma longa jornada, mergulhado em uma velocidade que sugere a da luz, o último astronauta chega a um ambiente futurista e encontra a si mesmo. Rapidamente o tempo passa e a cada corte de cena, ele envelhece, até o momento em que, em seu leito de morte, vislumbra a enigmática pedra negra e vê a si próprio como um feto, um porvir humano pleno de possibilidade, flutuando no espaço.

Santos (1987: 39-40) acrescenta:

O conhecimento do paradigma emergente tende assim a ser um conhecimento não dualista, um conhecimento que se funda na superação das distinçôes tão familiares e óbvias que até há pouco considerávamos insubstituíveis, tais como natureza/cultura, natural/artificial, vivo/inanimado, mente/matéria, observador/ observado, subjetivo/objetivo, coletivo/individual, animal/pessoa.

A superação da dicotomia ciências naturais/ciências sociais tende a revalorizar os estudos humanísticos. Assim, essa superação coloca a concepção humanística das ciências sociais como agente catalisador e a pessoa, enquanto autor e sujeito do mundo, no centro do conhecimento, todavia, ao contrário das humanidades tradicionais, dispóe o que hoje designamos por natureza no centro da pessoa. "Não há natureza humana porque toda a natureza é humana" (Santos, 1987: 44).

Vale ressaltar aqui que o processo da Reforma Psiquiátrica alinha-se com essa perspectiva, ao propor a desconstrução dos paradigmas fundantes 
da psiquiatria, que, sob a égide do racionalismo científico moderno, operam uma simplificação e estabelecem dicotomias entre saúde/doença e normal/patológico. Não há explicação baseada na causalidade biológica, capaz de dar conta da complexidade do existir e do sofrer humano. A ruptura epistemológica da Reforma Psiquiátrica propõe que o homem, e não a bioquímica dos neurotransmissores, esteja no centro.

- Todo conhecimento é local e total.

Uma das marcas mais evidentes da ciência moderna é a especialização. O conhecimento avança por ela e será tanto mais rigoroso quanto mais restrito seu objeto. Quanto a isso, Santos (1987: 46) ressalta:

Sendo um conhecimento disciplinar, tende a ser um conhecimento disciplinado, isto é, segrega uma organização do saber orientada para policiar as fronteiras entre as disciplinas e reprimir os que as quiserem transpor. É hoje reconhecido que a excessiva parcelização e disciplinarização do saber científico faz do cientista um ignorante especializado.

Já no paradigma emergente, o conhecimento é total e também local, pois se constitui ao redor de temas que,

em um dado momento são adotados por grupos sociais concretos como projetos de vida locais, sejam eles reconstituir a história de um lugar, manter um espaço verde, construir um computador adequado às necessidades locais, fazer baixar a taxa de mortalidade infantil, inventar um novo instrumento musical, erradicar uma doença, etc., etc. (Santos, 1987: 47-48)

A busca do conhecimento total nos leva não apenas a transpor as rígidas fronteiras entre as disciplinas, mas a reconstruí-las em uma perspectiva que supera os campos disciplinares, estabelecendo um constante diálogo transdisciplinar.

Novamente aqui temos uma grande aproximação com a Reforma Psiquiátrica. Ao romper com a visão biológica reducionista e produzir uma desmontagem dos conceitos basilares da psiquiatria, ela propóe construir/ tecer/inventar o seu campo teórico-conceitual, estabelecendo um amplo, profundo e radical diálogo entre as diferentes disciplinas e conhecimentos que tratam do humano.

Outro conceito-chave proposto pela Reforma Psiquiátrica e que constrói uma identidade com o proposto por esse paradigma emergente é o do 
território, que nos remete ao conceito do conhecimento local. Território é aqui entendido não apenas como a configuração de um espaço geográfico, mas refere-se às forças vivas de uma dada comunidade, com sua cultura, seus problemas, suas prioridades e potencialidades locais. O espaço, sobre o qual a ação da Reforma Psiquiátrica vai incidir, está intrinsecamente ligado a esse conceito. Um serviço substitutivo deve necessariamente ser pensado como um dispositivo que tece (no sentido de trabalhar a urdidura e a trama) e ativa uma rede de cuidados.

- Todo conhecimento é autoconhecimento.

A ciência moderna consagrou o homem enquanto sujeito epistêmico, mas expulsou-o, tal como a Deus, enquanto sujeito empírico. Um conhecimento objetivo, factual e rigoroso não tolerava a interferência dos valores humanos e religiosos. Foi nesta base que se construiu a distinção dicotômica sujeito/objeto. (Santos, 1987: 48)

Para as ciências humanas, essa distinção nunca foi pacífica, porque seus objetos de estudos eram homens e mulheres, tais como os pesquisadores que se propunham estudá-los. Para contemplar a distância epistemológica entre sujeito e objeto, criou-se uma distância empírica entre eles.

No paradigma emergente, assume-se a implicação do sujeito no processo de produção de conhecimento, tendo um caráter autobiográfico e autorreferenciável. Caracteriza-se como um conhecimento compreensivo e íntimo, que nos une pessoalmente ao que estudamos, aproximando a criação científica da criação literária ou artística. Temos assim uma ciência autoral que cria um conhecimento que nos ensina a viver e traduz-se num saber prático.

O campo da Reforma Psiquiátrica trata essencialmente do humano. Produzir uma radical ruptura com a dicotomia sujeito/objeto nos lança frente a frente com a complexidade do existir, com a dor em suas múltiplas dimensōes, com nossos próprios limites e potencialidades como atores e agentes do cuidado e da produção de conhecimento. Não há como fazer do sujeito um objeto sem deixar de conhecê-lo como sujeito e sem considerar que aquele que olha está implicado nesse encontro.

Nesse sentido, somos todos um pouco autores de múltiplas narrativas dos encontros possíveis e impossíveis, buscando construir um conhecimento que ajude a inventar possibilidades mais autônomas de existir e de conviver. 
- Todo conhecimento científico visa a constituir-se em senso comum.

Para Santos (1987: 55), a ciência moderna produz conhecimentos e desconhecimentos. Com ironia, afirma que "se faz do cientista um ignorante especializado, faz do cidadão comum um ignorante generalizado".

Ao contrário, o paradigma emergente sustenta que nenhuma forma de conhecimento é, em si mesma, racional; somente a configuração de todas elas é racional. Tal paradigma tenta, pois, dialogar com outras formas de conhecimento, deixando-se penetrar por elas. E, de todas, a mais importante é o conhecimento do senso comum, o conhecimento vulgar e prático que orienta as nossas açóes no cotidiano e dá sentido à vida.

A ciência moderna constituiu-se em oposição ao senso comum, que a tomava por superficial, ilusória e falsa. Santos propõe a ideia de uma dupla ruptura epistemológica: após a diferenciação entre a ciência e o senso comum, um outro ato epistemológico; romper com a primeira ruptura e transformar o conhecimento científico em senso comum. Em outras palavras, significa "romper com o senso comum conservador, mistificado e mistificador, não para criar uma forma autônoma e isolada de conhecimento superior, mas para transformar a si mesmo num senso comum novo e emancipatório" (Santos, 2001: 107).

Um dos campos de transformação propostos pela Reforma Psiquiátrica é o campo sociocultural. Trata-se aqui de operar transformações no imaginário social sobre a loucura, a doença mental etc. Quer dizer, propõe-se que todo conhecimento produzido por esse processo seja incorporado como um bem cultural, que faça parte do senso comum.

Contrariamente à afirmação de que "lugar de louco é no hospício", busca-se provocar e transformar a cultura para uma concepção mais inclusiva e acolhedora à diferença.

\section{A REFORMA PSIQUIÁTRICA E A TRANSIÇÃO PARADIGMÁTICA}

A Reforma Psiquiátrica é um processo social complexo que transcende e supera as reformulações na organização dos serviços de saúde e as propostas de implementação de caráter exclusivamente técnicas. Supõe a renúncia da vocação terapêutica instituída por intermédio da superação do paradigma 
psiquiátrico, o que significa negar a instituição manicomial, romper com a racionalidade e o saber psiquiátrico sobre a doença mental, compreendido como um processo histórico e social de apropriação da loucura; questionar o poder do especialista (psiquiatra, psicólogo, enfermeiro etc.) em relação ao paciente e negar o seu mandato social de custódia e exclusão. Frisa Amarante (1997: 165):

Se fosse oportuno, neste contexto complexo, questionar-se quanto ao principal objetivo da Reforma Psiquiátrica, talvez fosse possível responder que seria poder transformar as relações que a sociedade, os sujeitos e as instituições estabeleceram com a loucura, com o louco e com a doença mental, conduzindo tais relações no sentido da superação do estigma, da segregação, da desqualificação dos sujeitos ou, ainda, no sentido de estabelecer com a loucura uma relação de coexistência, de troca, de solidariedade, de positividade e de cuidados.

Como já destaquei anteriormente, a palavra 'reforma', utilizada na designação da Reforma Psiquiátrica, ${ }^{35}$ não faz jus, pelos problemas que o termo provoca, à riqueza e à complexidade do que aqui estou a relatar. Em diálogo com Foucault, a respeito da relação entre os intelectuais e o poder, Deleuze critica a noção de reforma, afirmando:

Ou a reforma é elaborada por pessoas que se pretendem representativas e que têm como ocupação falar pelos outros, em nome dos outros, e é uma reorganização do poder, uma distribuição de poder que se acompanha de uma repressão crescente. Ou é uma reforma reivindicada, exigida por aqueles a que ela diz respeito, e aí deixa de ser uma reforma, é uma ação revolucionária que por seu caráter parcial está decidida a colocar em questão a totalidade do poder e de sua hierarquia. (Foucault, 1979: 72)

Construir uma conceituação 'forte ${ }^{936}$ da Reforma Psiquiátrica é pensála como uma ação revolucionária desse tipo. Trata-se de uma radical ruptura com o modelo asilar predominante, por meio não só de um questionamento de seus conceitos, fundamentos e de suas práticas moldadas em uma questionável racionalidade científica, mas, principalmente, da construção de novo paradigma científico, ético e político. É nessa ruptura

\footnotetext{
${ }^{35}$ Amarante (2003), autor em parte responsável pela divulgação do termo Reforma Psiquiátrica, apresenta uma discussão na qual informa e contextualiza a sua origem, os seus usos e os sentidos.

${ }^{36}$ Conforme expus na Apresentação deste trabalho.
} 
que entendo o conceito de Reforma Psiquiátrica e não apenas no sentido de uma mudança de lócus e de técnicas de cuidado e gestão de serviços de saúde mental.

A crítica radical à psiquiatria tradicional, efetuada desde os anos 70 , produziu uma mudança na concepção do objeto, focado na doença, com uma decorrente prática centrada quase que exclusivamente na figura do médico, para uma concepção que busca superar as dicotomias saúde/doença, individual/social. Constituiu um campo complexo, composto por uma rede de fatores sociais, psicológicos, culturais e biológicos. Nessa perspectiva, trata-se de tomar o drama do existir humano em sua complexidade.

Costa-Rosa (2000) nomeia o conjunto das práticas promovidas pela Reforma Psiquiátrica como "modo psicossocial”, em um movimento dialético de contradição ao modelo psiquiátrico tradicional, o qual chama de "modo asilar" predominante. Para o autor, a fim de caracterizar a mudança de paradigma de atenção capaz de superar o modelo asilar, é imprescindível que a prática preencha algumas condições relativas a transformações radicais em quatro âmbitos:

1) Concepção do objeto e dos meios de trabalho: contrapondo-se à ênfase nas determinações orgânicas e sua decorrente prática e ao meio de trabalho que reproduz modelo da divisão de trabalho correspondente à linha de montagem', o modo psicossocial caracteriza-se pela transformação nas concepções do objeto e na participação e implicação do sujeito no tratamento, tendo como meio de trabalho a equipe interprofissional, que, pelo intercâmbio entre seus saberes e práticas, supera radicalmente o modelo da linha de montagem.

2) Concepçōes das formas da organização institucional: opondo-se à organização verticalizada e a um fluxo de poder em sentido único do modo asilar, o modo psicossocial se caracteriza por uma organização institucional dos dispositivos de trabalho horizontal, no qual a participação, autogestão e interprofissionalidade são as metas radicais.

3) Formas do relacionamento com a clientela: enquanto o modo asilar se caracteriza pela separação entre doentes e sãos, com a instituição cumprindo uma função de depositária que interdita o diálogo, no modo psicossocial propõe-se que a instituição, por meio de seus agentes, adquira o caráter de espaço de interlocução, agenciadora de subjetividades. E, tendo 
em vista a dimensão de suas ações no âmbito da saúde coletiva, a instituição deve funcionar como ponto de fala e escuta da população.

4) Concepção dos efeitos típicos em termos terapêuticos e éticos: enquanto no modo asilar se observa uma hipertrofia nos 'defeitos de tratamento', como a cronificação asilar, decorrente de um entendimento do tratamento centrado na supressão ou no tamponamento dos sintomas, o modo psicossocial objetiva o reposicionamento subjetivo, levando-se em conta a dimensão coletiva e sociocultural. Deverá ser pensado na perspectiva de uma ética que se abra para a 'singularização'. Assim, implicação subjetiva e sociocultural, além da singularização, são as metas radicais quanto à ética das práticas no modo psicossocial.

Tenho como eixo central deste trabalho as quatro dimensões fundamentais do processo da Reforma Psiquiátrica apresentadas por Amarante (2003). Descreverei a seguir as características de cada uma delas, acrescentando minhas contribuições pessoais.

A DimENSÃo EPISTEMOlÓGICA: é a que estou a tratar neste capítulo, e se refere ao campo da produção de saberes e à desconstrução dos fundamentos, das noçôes e dos conceitos fundantes da psiquiatria, como, por exemplo, a noção de doença mental. Não se trata apenas de negar, romper, mas também de produzir novas noções e conceitos, tecendo linhas que dialogam e articulam diferentes disciplinas, num esforço de construir um novo paradigma no campo da saúde mental.

A DIMENSÃO TÉCNICO-ASSISTENCIAL: em um constante movimento entre a prática e a teoria, ou seja, no movimento de uma práxis, propõe-se a construção de uma nova organização de serviços, articulando uma rede de espaços de sociabilidade, de produção de subjetividades, de geração de renda, de apoio social, de moradia, enfim, de produção de vida.

A DIMENSĀO JURÍDICO-POLÍTICA: no primeiro capítulo, sugeri uma pequena alteração, renomeando-a como dimensão política. O termo jurídico colocado à frente, embora não seja essa a ideia fundamental, remete a uma ênfase nas mudanças das leis. O sentido da alteração é salientar o processo de ação de protagonistas em diferentes segmentos sociais (movimento social, reforma do Estado, universidades etc.). São ações que objetivam construir uma nova pactuação de poder, lutando para dar voz a quem não tem direito, a quem não é cidadão. Trata-se, enfim, de uma luta política para uma transformação social. 
A DIMENSÃO SOCIOCULTURAL: há um imaginário social, construído historicamente, para a loucura, para a diferença. Um imaginário que desqualifica ("Isso é coisa de louco!"), que exclui ("Lugar de louco é no hospício!"), que teme ("Louco é perigoso e agressivo!"), que infantiliza ("Que bonitinho! Nem parece feito por louco!"). Provocar a sociedade a refletir sobre sua relação com a loucura, com objetos e açôes culturais. Transformar, como diz Santos, o conhecimento e as práticas em um senso comum emancipatório. Enfim, produzir uma transformação desse imaginário é o grande desafio desta dimensão.

Em O Homem e a Serpente, Amarante sublinha a importante contribuição da produção de Franco Basaglia, psiquiatra italiano, referência teórica e prática da Reforma Psiquiátrica, a qual "pode ser entendida como um importante marco de referimento de uma 'fase de transição' do paradigma psiquiátrico-moderno, que se situa numa transição maior, que é a da ciência da modernidade" (Amarante, 1996: 24).

Como marco exemplar dessa transição, podemos destacar uma das principais proposiçôes basaglianas, inspirada na filosofia fenomenológica de Husserl, a de "colocar a doença entre parênteses". Trata-se de uma inversão da operação produzida pela racionalidade positivista da psiquiatria, que colocou o sujeito entre parênteses e se limitou à "definição das síndromes em que o doente, arrancado de sua realidade e apartado do contexto social em que vive, vê-se etiquetado, 'constrangido' a aderir a uma doença abstrata, simbólica e, enquanto tal, ideológica” (Basaglia, 2005: 35).

Com essa inversão, Basaglia propõe uma importante demarcação epistemológica que diz respeito ao saber psiquiátrico que se construiu em torno das definições abstratas de doença, as quais reduzem o sujeito a uma coleção de sintomas e sinais, a uma espécie catalogável e categorizável e que tem consequências éticas e políticas.

Para Amarante (1996: 84-85),

a doença entre parênteses é, ao mesmo tempo, a denúncia e a ruptura que permite a observação do duplo da doença mental, isto é, do que não é próprio da condição de estar doente, mas de estar institucionalizado (e não apenas internado), que reabre a possibilidade de um outro conhecimento sobre esta mesma condição. 
Nessa perspectiva, surge outro importante conceito para a Reforma Psiquiátrica: a desinstitucionalização. Formulado no âmbito da experiência italiana, tal conceito amplia os horizontes teóricos e técnicos do campo da saúde mental e tem inspirado e orientado boa parte dos trabalhos desenvolvidos no Brasil. Segundo o autor,

a desinstitucionalização na psiquiatria, na tradição basagliana, inscreve-se neste período de transição, onde se inicia uma fase de afastamento do paradigma clássico, com sua desmontagem, e a conseqüente abertura de um novo contexto prático-discursivo sobre a loucura e o sofrimento humano. Isso significa que, ao abrir um processo de recomplexificação da loucura, contribui com algumas estratégias cognitivas e práticas para o campo da teoria das ciências e do conhecimento (Amarante, 1996: 31)

E, finalmente, o autor enfatiza uma característica do processo de desinstitucionalização, que podemos considerar como a face mais marcante e mais cotidiana do processo da Reforma Psiquiátrica brasileira: a possibilidade de

construir e inventar novas perspectivas de vida e subjetividade para aqueles mesmos sujeitos, e não apenas 'evoluçōes' e 'prognósticos' da doença mental (...) A complexidade, enfim, reporta ao problema ético das relaçôes entre os homens e para com a natureza, porque coloca o problema do pensar e agir em termos de relações e não de objetos. (Amarante, 1996: 33)

Esta não é apenas uma ruptura epistemológica aos fundamentos do saber e da prática da psiquiatria. A Reforma Psiquiátrica insere-se em um campo mais amplo, o da Reforma Sanitária, que tem configurado um novo campo, o da saúde coletiva.

Paim e Almeida Filho (1998) discutem o paradigma da saúde pública, concluindo que, apesar de não preencher as condiçôes epistemológicas para se constituir em um novo paradigma, a saúde coletiva, enquanto movimento ideológico comprometido com a transformação social, evidencia possibilidades de articulação com novos paradigmas científicos capazes de abordar o objeto saúde-doença-cuidado respeitando sua historicidade e integralidade. Apresentam-na como um campo científico e um âmbito de práticas aberto à incorporação de propostas inovadoras. 


\section{Esclarecem os autores:}

A partir destas reflexões, constata-se a afirmação de um campo interdisciplinar dinâmico, renovado e recomposto a partir de uma produção teórica ousada e consistente, ainda enfrentando diversas interrogaçōes e dilemas. De fato, a conjunção das "crises da saúde" - científica, econômica, social e política - lança complexos desafios para a saúde coletiva quanto ao que fazer para efetivamente se articular aos novos paradigmas da saúde para o século XXI. (Paim \& Almeida Filho, 1998: 312)

Assim como na Reforma Psiquiátrica, trata-se aqui, no âmbito da produção de conhecimento, de reconfigurar o objeto privilegiado 'saúde'. Os autores destacam a necessidade de uma apreensão pragmática alimentando uma práxis, em vez de constituir-se em mera produção e incorporação de tecnologia:

Muito do que em um dado paradigma se pode tomar como um aparente paradoxo deve-se ao fato de que não se lida com um objeto obediente às determinações da predição, aquela das antecipações limitadas e limitantes, rigorosas e precisas. Efetivamente, o objeto da saúde coletiva é muito mais tolerante a formas aproximadas de antecipação do seu processo, ressaltando a natureza nãolinear da sua determinação e a imprecisão (ou borrosidade) dos seus limites. (Paim \& Almeida Filho, 1998: 312)

A ruptura com os paradigmas vigentes não deve se restringir a um movimento de recusa e denúncia. A ruptura radical implica todos os atores envolvidos nesse amplo campo em intensos e incessantes movimentos de crítica, elaboração e superação. É um movimento processual, que mobiliza os desejos dos atores e sujeitos no âmbito da práxis e que provoca uma transformação e uma construção no plano epistemológico, as quais retornam e alimentam o pensamento e a ação.

\section{CONCLUSÃO}

Ao longo deste capítulo, busquei explicitar as principais características do que poderia chamar de uma ruptura paradigmática. Embora, no transcorrer dos anos, encontremos inúmeras experiências singulares que, de certa forma, já se fundamentavam em alguns desses conceitos, é a partir da 
Reforma Psiquiátrica que essa ruptura, operada e concretizada cotidianamente na prática das novas instituiçôes, conquistou maior visibilidade. Foi contagiando e contaminando outros operadores, outros profissionais, que foram criando e inventando outras instituições e outras novas práticas.

No Quadro 1, sintetizo alguns elementos que julgo essenciais para compreender essa transição de um modelo a outro. Em uma das colunas, caracterizo o modelo psiquiátrico tradicional que se fundamenta na racionalidade médica. Já para o novo paradigma, exatamente por estar sendo tecido, marcado por sua imprecisão, sua transitoriedade, irei nomeá-lo duplamente: como atenção psicossocial ${ }^{37}$ e como novo modelo assistencial, tal como propõem os documentos oficiais do Ministério da Saúde.

O modelo psiquiátrico tradicional, construído historicamente a partir do século XVIII, tem como objeto central de seu domínio e de sua intervenção a doença mental. Há um distúrbio que se localiza no corpo e que se manifesta em alterações nas formas de ser e de existir do sujeito, fugindo a um padrão de normalidade. Esse distúrbio pode ser reduzido, em sua determinação, a fatores localizáveis no organismo.

Quadro I - Principais características do modelo psiquiátrico e da atenção psicossocial

\begin{tabular}{|lll|}
\hline & Modelo psiquiátrico & $\begin{array}{l}\text { Atenção psicossocial/ } \\
\text { Novo modelo assistencial }\end{array}$ \\
\hline Objeto & Simples doença mental & $\begin{array}{l}\text { Complexo } \\
\text { existência-sofrimento }\end{array}$ \\
\hline Pressuposto teórico-conceitual & Campo das neurociências & Campo transdisciplinar \\
\hline Estratégias de intervenção & $\begin{array}{l}\text { Isolamento e } \\
\text { predominantemente biológica }\end{array}$ & $\begin{array}{l}\text { Predominância da diversidade } \\
\text { e da invenção }\end{array}$ \\
\hline Agente do cuidado & Médico & Coletivos \\
\hline Lugar do cuidado & Hospitalização & Rede e intersetorialidade \\
\hline Prática social & Exclusão/violência & Inclusão e solidariedade \\
\hline
\end{tabular}

Este olhar sobre o objeto pressupõe um marco teórico-conceitual e instrumentos de análise que se situam no campo da psiquiatria, que, ainda

${ }^{37}$ Conforme apresentado no texto Atenção Psicossocial: rumo a um novo paradigma na saúde mental coletiva, de Costa-Rosa, Luzio e Yasui (2003). 
carente de consistência científica, almeja estabelecer relações e ingressar no campo das neurociências.

A estratégia de intervenção, que daí decorre, será predominantemente biológica, ou seja, essencialmente psicofarmacológica, sendo que outras disciplinas comparecem apenas como coadjuvantes. $\mathrm{O}$ isolamento será a estratégia adequada para o enfrentamento das crises que não podem ser silenciadas.

Objeto, marco teórico e estratégia de intervenção definem uma lógica assinalada pela racionalidade científica, a qual terá, na figura do médico, o seu principal agente do cuidado, tendo como consequência a subordinação da prática de outros profissionais à sua decisão e orientação, caracterizando assim um modelo médico-centrado e uma hierarquização das profissões no interior das instituições.

Isolar para conhecer e conhecer para dominar. Estes são os postulados que legitimaram o hospital psiquiátrico como lócus desse paradigma. Porém, sua lógica não se restringe ao espaço físico asilar e se atualiza mesmo nas instituições que, aparentemente, se propõem alinhadas com os modelos substitutivos.

A prática social decorrente desse modo é a do controle social, da exclusão do diferente e da violência institucionalizada.

Já a atenção psicossocial vem sendo tecida ao longo dos últimos anos, com os múltiplos fios de diversas disciplinas e experiências concretas. Rompendo com o paradigma psiquiátrico e, por conseguinte, com a racionalidade médica, trata-se aqui de tomar a existência humana em sua complexidade. E, nela, o sofrimento psíquico.

Falar de sofrimento significa falar da dor do corpo, da ansiedade, da angústia. Sofrimento também remete ao sofrimento de viver, das dificuldades impostas pelo modo de vida, marcado pela dimensão social, pela penúria, pela miséria. Do sertão que há em toda parte. Agregar o termo 'psíquico' à palavra 'sofrimento' não significa estabelecer uma divisão ou um corte entre mente/corpo. Significa enfatizar. Olhamos para a complexidade da existência humana por esse viés da singularidade, da subjetividade. Ou seja, incluímos essa dimensão que compreende uma intrínseca relação entre o conjunto de conteúdos da consciência e do inconsciente humano, que estão presentes nos estados e processos da experiência subjetiva e que se constituem/constroem/ tecem na relação do sujeito com o seu entorno social, familiar, cultural etc. 
Se entendemos o sofrer e a vida, em sua complexidade, só poderemos assumir, como pressuposto teórico, algo da ordem que contemple e sustente tal diversidade de olhares. Estamos, pois, no campo nomeado por Morin como o da complexidade, ou, por Santos, como de um paradigma prudente para uma vida decente, ou de Prigogine e Stengers, como o de uma "nova aliança”. Adota-se uma postura de profunda humildade frente à diversidade e de um aberto e intenso diálogo, que cruza e perpassa as diferentes disciplinas.

Desta perspectiva e marco teórico, somente podemos então pensar em estratégias de cuidado que produzam e promovam a autonomia e a singularização do sujeito. E estas serão, também, da ordem da diversidade e da multiplicidade. Nesse sentido, o conceito de clínica se transforma. Não uma clínica inspirada no reclinar-se sobre o leito do paciente, com olhar de quem observa e busca a doença. Lugar onde as identidades dos participantes estão predefinidas. Mas uma clínica do encontro, da invenção e da produção de sentidos.

Assim, o lugar será qualquer um onde houver possibilidade de encontro com a vida e com a autonomização do sujeito. Um serviço substitutivo deve necessariamente ser pensado como um dispositivo que tece (no sentido de trabalhar a urdidura e a trama) e ativa uma rede de cuidados.

Os agentes serão os coletivos, mais do que as equipes multiprofissionais que apenas se constituem de profissionais compartilhando um mesmo espaço. Serão os cuidadores de distintas profissões e de distintas instituições dispostos a articular e a construir/inventar esse dispositivo de cuidado. E mais além: serão os familiares, os amigos, os colegas da escola, do trabalho, enfim, todo aquele que se puder implicar nesta ampla rede de cuidados.

Há uma ética que perpassa todo esse trabalho. Ele só pode ser concretizado como uma prática social que sonha utopias, que trabalha e acredita em uma sociedade mais justa e igualitária, que respeite radicalmente as diferenças. Só pode ser então uma prática norteada pela perspectiva da transformação social, ainda que ela seja uma utopia. Todavia, que seja uma utopia ativa, cujo percurso se concretiza a cada gesto cotidiano de cuidado com o sofrimento psíquico.

Se o sertão está em toda a parte, há que se encontrar as veredas e, igualmente, há que se construir veredas. Há que ser tão veredas. 